\title{
Anoxic sediments off Central Peru record interannual to multidecadal changes of climate and upwelling ecosystem during the last two centuries
}

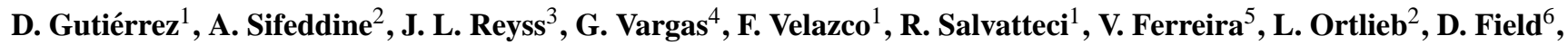 \\ T. Baumgartner ${ }^{5}$, M. Boussafir ${ }^{7}$, H. Boucher ${ }^{2}$, J. Valdés $^{8}$, L. Marinovic ${ }^{7}$, P. Soler ${ }^{9}$, and P. Tapia ${ }^{10}$ \\ ${ }^{1}$ Dirección de Investigaciones Oceanográficas, Instituto del Mar del Perú, P.O. Box 22, Callao, Peru \\ ${ }^{2}$ UR Paléotropique, Institut de Recherche pour le Développement, IRD, Bondy, France \\ ${ }^{3}$ Laboratoire du Sciences de Climat et le Environnement, CEA/CNRS, Gif-Sur-Yvette, France \\ ${ }^{4}$ Departamento de Geología, Facultad de Ciencias Físicas y Matemáticas, Universidad de Chile, Chile \\ ${ }^{5}$ Centro de Investigación Científica y de Educación Superior de Ensenada, Ensenada BC, Mexico \\ ${ }^{6}$ Fisheries Resources Division, Southwest Fisheries Science Center, La Jolla, USA \\ ${ }^{7}$ Institut des Sciences de la Terre (ISTO), Université de Orléans, Orléans, France \\ ${ }^{8}$ Laboratorio de Sedimentología y Paleoambientes, Universidad de Antofagasta, Chile \\ ${ }^{9}$ UMR LOCEAN, Université Paris VI/IRD/CNRS/MNHN, France \\ ${ }^{10}$ Laboratorio de Palinología y Paleobotánica, Universidad Peruana Cayetano Heredia, Peru
}

Received: 20 July 2005 - Revised: 21 November 2005 - Accepted: 21 November 2005 - Published: 9 January 2006

\begin{abstract}
High-resolution paleo-environmental and paleoecological archives in laminated sequences are present in selected areas from the upper continental Peruvian margin within the oxygen minimum zone. We present initial results of a multidisciplinary study (the PALEOPECES project) that aims to reconstruct environmental and ecosystem variability during the past 200 years from high-resolution records. We report chronology development, sediment structure, elemental, organic, and mineralogical compositions of a box core collected at $300 \mathrm{~m}$ depth off Pisco, central Peru. An average sedimentation rate of $2.2 \mathrm{~mm} \mathrm{y}^{-1}$ was estimated from downcore excess ${ }^{210} \mathrm{~Pb}$ activities for the last $100-150$ years. Extending this rate further downcore indicates that a slump located at $52 \mathrm{~cm}$ depth from the top of the core can be correlated with a large tsunami that struck the coast of central Peru in 1746. X-ray analyses reveal laminated structures composed of couplets of light and dark laminae. Observations under polarized microscope show that light laminae are dominated by more dense, detrital and terrigenous material, while dark laminae are less dense with greater concentrations of amorphous biogenic silica. Downcore variations in dry bulk density and X-ray radioscopy of gray level show similar patterns, including a major shift at $34 \mathrm{~cm}$ depth (ca. mid-nineteenth century). A finely laminated sequence, which may include annual varves, is present between $34 \mathrm{~cm}$ depth and the slump layer. Sediment characteristics of the
\end{abstract}

Correspondence to: D. Gutiérrez

(dgutierrez@imarpe.gob.pe) sequence suggest increased seasonality of terrigenous versus biogenous sedimentation during the corresponding period. In addition to a mid-nineteenth century change and considerable multidecadal variability in TOC, there is a positive trend in the past 50 years. Mineralogical analyses from a Fourier Transformed Infrared Spectroscopy (FTIR) of the upper core covering the last 25 years, indicate higher concentrations of the mineral fraction (quartz, feldspar, kaolinite and illite) in layers including large El Niño events (1982-1983, 19861987 and 1997-1998), with the largest peak during the 19971998 episode. These results confirm that anoxic sediments off Pisco are suitable archives to investigate interannual and decadal changes in oceanographic conditions and climate of the northern Humboldt upwelling system.

\section{Introduction}

The Humboldt Current Ecosystem (HCE) off Peru undergoes large variations in productivity and ecosystem structure in association with the El Niño Southern Oscillation (ENSO), and decadal variability (Arntz and Fahrbach, 1996; Alheit and Niquen, 2004). Changes on decadal time scale are recognized as important sources of variability in atmospheric and oceanic structure (Miller, 1994; Field and Baumgartner, 2000). Decadal variability may also modulate the frequency, intensity and timing of the ENSO cycle (Wang and Picaut, 2004; Wang et al., 2004; Wang and Fiedler, 2005; Cobb et al., 


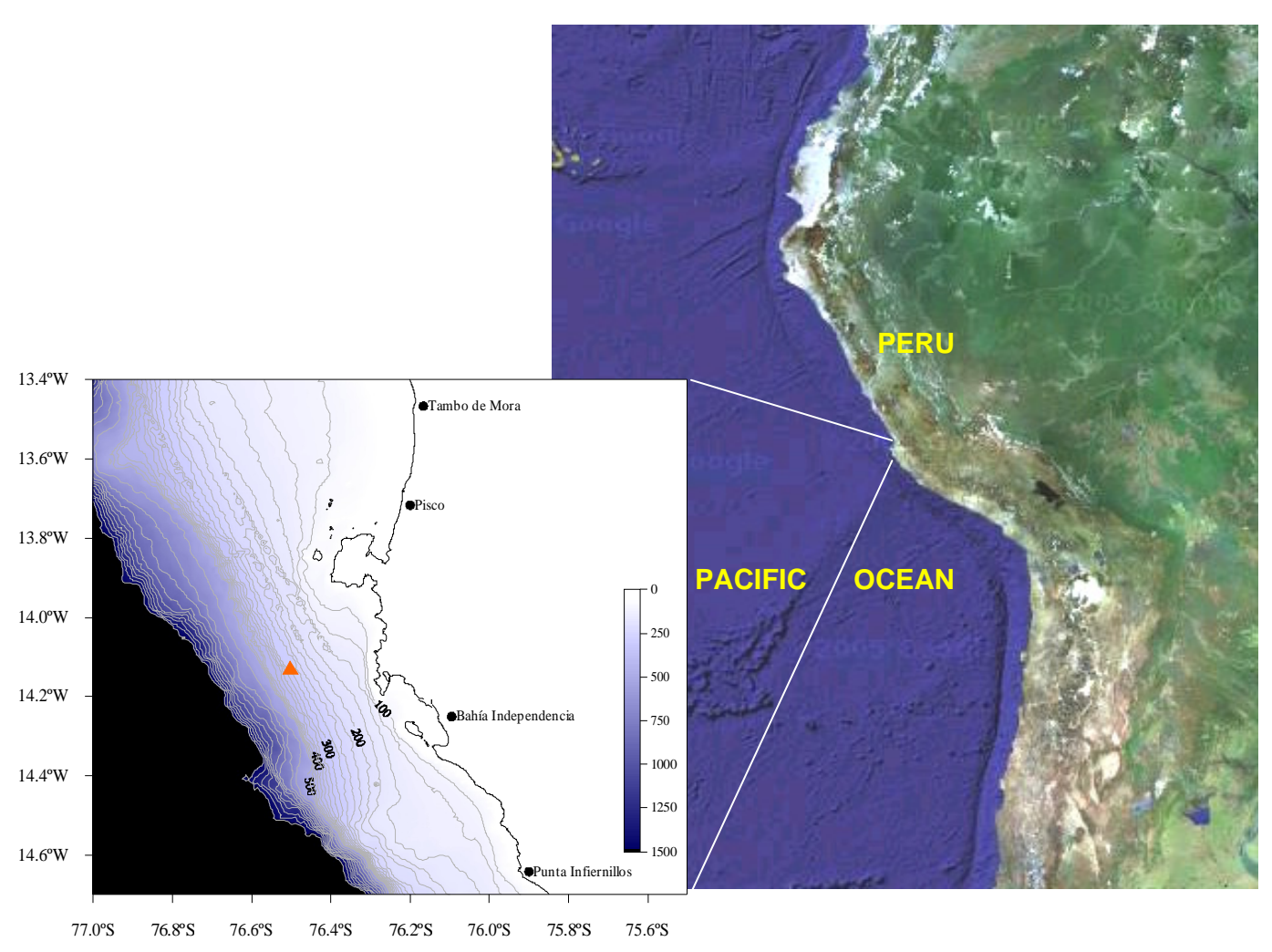

Fig. 1. Location of boxcore B0405-06 (red triangle, $14^{\circ} 07.9^{\prime} \mathrm{S}, 76^{\circ} 30.1^{\prime} \mathrm{W}, 299 \mathrm{~m}$ depth) off the central-south Peruvian coast. Bathymetric contour lines are in $25 \mathrm{~m}$ intervals from $100 \mathrm{~m}$ to $500 \mathrm{~m}$, and in $100 \mathrm{~m}$ intervals from $500 \mathrm{~m}$ to $1500 \mathrm{~m}$ depth.

2004). These low frequency changes in the physical environment can result in large non-linear "regime shifts" in marine ecosystem structure in the Pacific Basin (Mantua and Hare, 2002; Schwartzlose et al., 1999; Hsieh et al., 2005). Within the HCE , two "anchovy regimes" (from the start of the fisheries until early 70s, and from early 90's until present) separated by a "sardine regime" (from mid 70's until early 90's) have been proposed (Chávez et al., 2003; Alheit and Ñiquen, 2004). However, the extent to which decadal changes observed in the twentieth century are typical of regular decadal variability is not known.

The presence of an oxygen minimum zone inhibits bioturbation and facilitates the preservation of high-resolution records of past ecosystem changes in disoxic sediments in suitable topographic conditions (Krissek and Scheiddeger, 1983). Seasonal and/or interannual differences in particle composition and density may result in the formation of annual varves or laminae (Kemp et al., 1990; Valdés et al., 2003). However, sediments of the Peru slope are highly heterogeneous; authigenic precipitation of phosphorites, erosive processes and lateral transport are influential processes that can frequently supersede deposition and preservation of continuous laminae in disoxic environments (Levin et al., 2002; Reinhardt et al., 2003). Therefore, continuous highresolution records in recent laminated sequences are present only in specific localities of the continental margin, particularly off the central Peruvian coast. Some studies in this zone have described laminated sediments containing natural archives of climate and ecosystem change, such as diatoms, organic carbon and fish scales (e.g. Kemp et al., 1990; Schwartzlose et al., 1999). However, to our knowledge, the present study is the first multiproxy approach conducted at high-resolution in sediments containing laminated sequences that record different modes of variability during the recent past.

PALEOPECES is an international, multidisciplinary, research project that aims to reconstruct past variability in environmental (temperature and oxygen) and ecosystem (productivity, ecosystem structure and fish population dynamics) characteristics of the Peruvian upwelling ecosystem during the last 2000 years, with an emphasis on the last several hundred years. Our general objective here is to describe the nature of these laminated sedimentary records and assess their suitability to reconstruct environmental and biological signals at multiannual and decadal time-scales during the past several hundred years. In the first stage, we conducted exploratory surveys that enabled us to pinpoint continental margin localities where high-resolution records are preserved. The present work summarizes the initial analyses of a core spanning longer than the last 200 years from one of the most favorable regions found. 
(a)

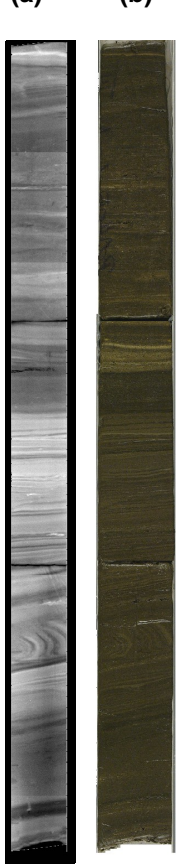

(c) $\quad \rho\left(\mathrm{g} \mathrm{cm}^{-3}\right)$

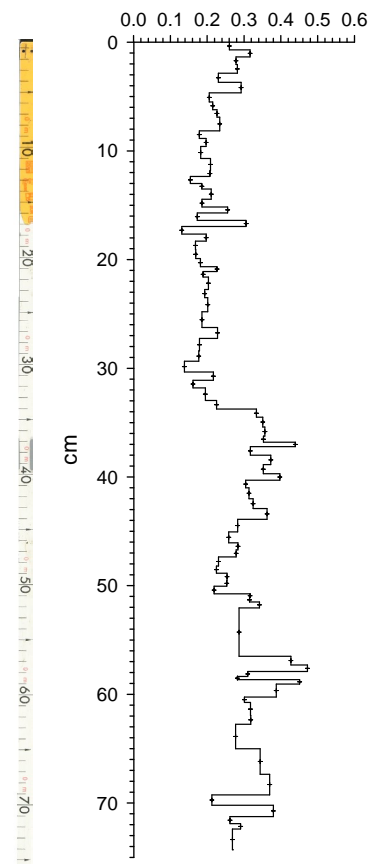

(d) gray level

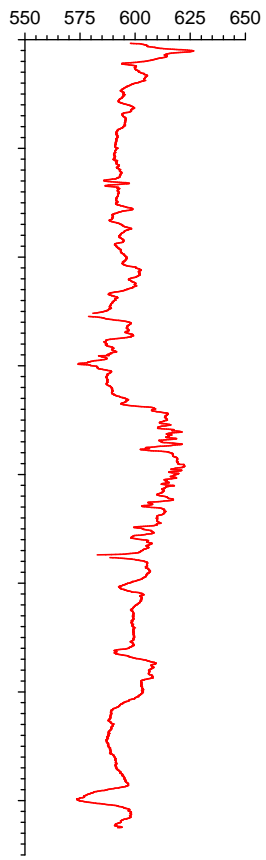

(e) TOC $(\%)$

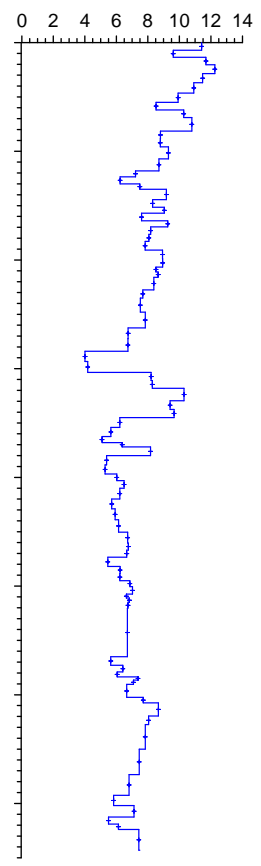

Fig. 2. Sedimentary characteristics of boxcore B0405-06. (a) Digital X-radiograph (SCOPIX), (b) digital photograph, (c) downcore distribution of dry bulk density ( $\rho$ ), (d) X-ray gray level (arbitrary units), and (e) percent total organic carbon (TOC) from boxcore B0405-06.

\section{Methodology}

\subsection{Environmental setting and sampling site}

Based on previous studies (Suess et al., 1990; Reinhardt et al., 2002; IMARPE, unpublished data), exploratory coring was done on the upper slope off Callao $\left(11^{\circ} 30^{\prime} \mathrm{S}-12^{\circ} 15^{\prime} \mathrm{S}\right)$ and Pisco $\left(13^{\circ} 15^{\prime} \mathrm{S}-14^{\circ} 00^{\prime} \mathrm{S}\right)$, at depths varying between 100 and $400 \mathrm{~m}$. This sampling involved a series of short Phleger gravity cores $(6.3 \mathrm{~cm}$ internal diameter and $63 \mathrm{~cm}$ length) taken on the R/V Olaya (May 2003). These sediment cores showed different types of structures, including homogeneous, banded, or laminated layers, sometimes with nodules and unconformable laminations. The most continuously laminated cores were collected off Pisco between 200 and $300 \mathrm{~m}$ depth. This area is located downstream from the main upwelling center off Peru (San Juan, at $15^{\circ} \mathrm{S}$ ) and within the core of the oxygen minimum zone (OMZ). The shelf-slope transition is smooth here and located around $350 \mathrm{~m}$ depth. A boxcore containing finely laminated sequences was retrieved using a Soutar Box Corer, off Pisco $\left(14^{\circ} 07.9^{\prime} \mathrm{S}, 76^{\circ} 30.1^{\prime} \mathrm{W}\right.$, 299 m depth) on a second cruise in May 2004 (Fig. 1).

\subsection{Analytical methods}

The relatively large area of the box core provided large sediment volume for small incremental downcore sub-sampling. The core was left to drain for several months before subsampling, which resulted in considerable core shrinkage. The core was then cut into four slabs of $2.5 \mathrm{~cm}$ thickness each for bulk sedimentological and microfossil subsampling, and two slabs of $1 \mathrm{~cm}$ thickness each for X-radiography, chronology development, and geochemical analyses. Subsampling for chronology work and for bulk sedimentology was performed with centimeter to sub-centimeter resolution following the stratigraphy. Sediment dry bulk density $(\rho)$ was estimated by mapping each sediment slice area and thickness.

Sedimentary structures were documented by analogic Xradiography and by high-resolution (sub-millimeter scale) digital X-radioscopy (SCOPIX, Migneon et al., 1999). Radioscopy outputs were expressed on a gray level scale that measures density-based differences in the transparency to Xrays, with higher gray levels indicating lower transparency due to greater density. The vertical distributions of excess ${ }^{210} \mathrm{~Pb}$ and other radionuclides were determined by gamma spectrometry at the Laboratoire des Sciences du Climat et l'Environnement, at Gif-Sur-Yvette, France. Gamma spectrometry on sediment samples was done with one highresolution, low background, "well-type" Ge detector at the Laboratoire Souterrain de Modane (Cochran, 1992; Reyss et al., 1995). In order to correct ${ }^{210} \mathrm{~Pb}$ gamma countings by self-absorption, radiochemical assays were run for some sediment samples previously spiked with ${ }^{208} \mathrm{Po}$, followed by alpha spectrometry. Sedimentation rates were obtained from a simple Constant Flux / Constant Supply Model (Appleby and Oldfield, 1978) using excess ${ }^{210} \mathrm{~Pb}$ downcore profiles. Complete chronologies are in progress from these ${ }^{210} \mathrm{~Pb}$ derived sedimentation rates and by radiocarbon ages corrected by local reservoir effects, as well as through comparisons of laminations, traces of slumps and biogenic structures. 


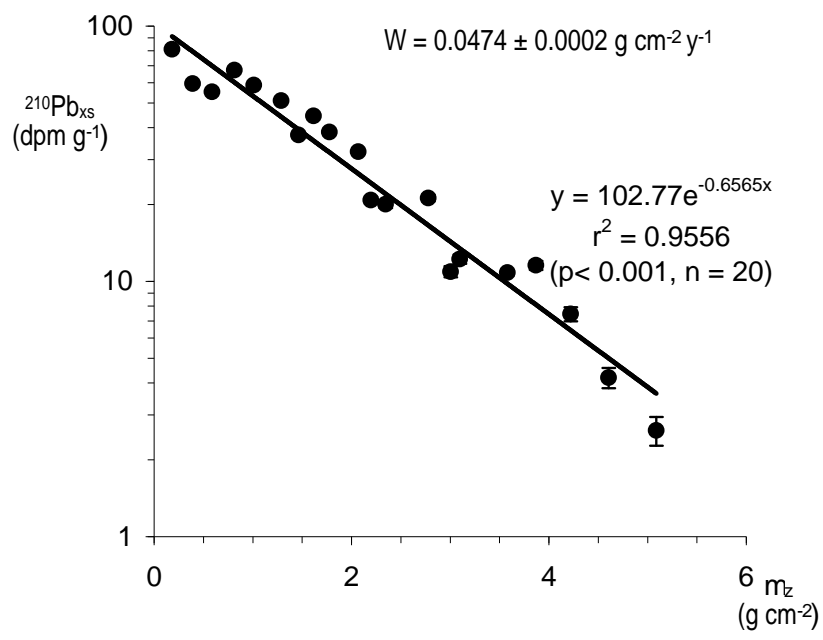

Fig. 3. Downcore distribution of excess ${ }^{210} \mathrm{~Pb}$ versus depthaccumulated mass. Regression line corresponds to the least-squares fit of the Constant Flux - Constant Sedimentation model and yields a mass accumulation rate of $0.0424 \pm 0.0024 \mathrm{~g} \mathrm{~cm}^{-2} \mathrm{y}^{-1}$.

Bulk elemental total organic carbon (TOC) was measured with a Thermo Electron CNS elemental analyzer (PALÉOTROPIQUE laboratory, Bondy). The mineralogical composition was assessed by Fourier Transformed Infrared Spectrometry (FTIR). Samples were prepared using a $\mathrm{KBr}$ disc, which ensures that Lambert-Beer's law is valid. A quantitative determination of the mineral content from various blends was performed by making a multicomponent analysis of the experimental spectrum using the spectra of each component in the mixture (Bertaux et al., 1998). Smearslides of selected samples were microphotographed under a polarized microscope in order to observe, describe, and quantify the biogenic and detrital particles.

\section{Results and discussion}

Sedimentary characteristics, including X-radiographs, gray level, dry bulk density $(\rho)$, and TOC values from the boxcore are shown in Fig. 2. Gray level varies positively with $\rho\left(r^{2}=0.45, n=83, p<0.001\right)$, indicating that sediment transparency to $\mathrm{X}$-rays is at least partly explained by changes in dry bulk density. A major change in the sediment structure is observed at $34 \mathrm{~cm}$ depth below the core top. Above this $34 \mathrm{~cm}$ level, sediments are less dense on average with coarser laminations and higher and more variable TOC content. Below this level sediments are characterized by greater density, finer laminations, and a lower, less variable, TOC content. A finely laminated sequence of $20 \mathrm{~cm}$ is located immediately below this transition and extends down to a slump segment at $52-55 \mathrm{~cm}$ depth. Couplets of dark and light laminae range from $2-5 \mathrm{~mm}$ thickness within the finely laminated sequence. Above the $34 \mathrm{~cm}$ transition, the thickness of the coarse couplets are $\sim 1 \mathrm{~cm}$.
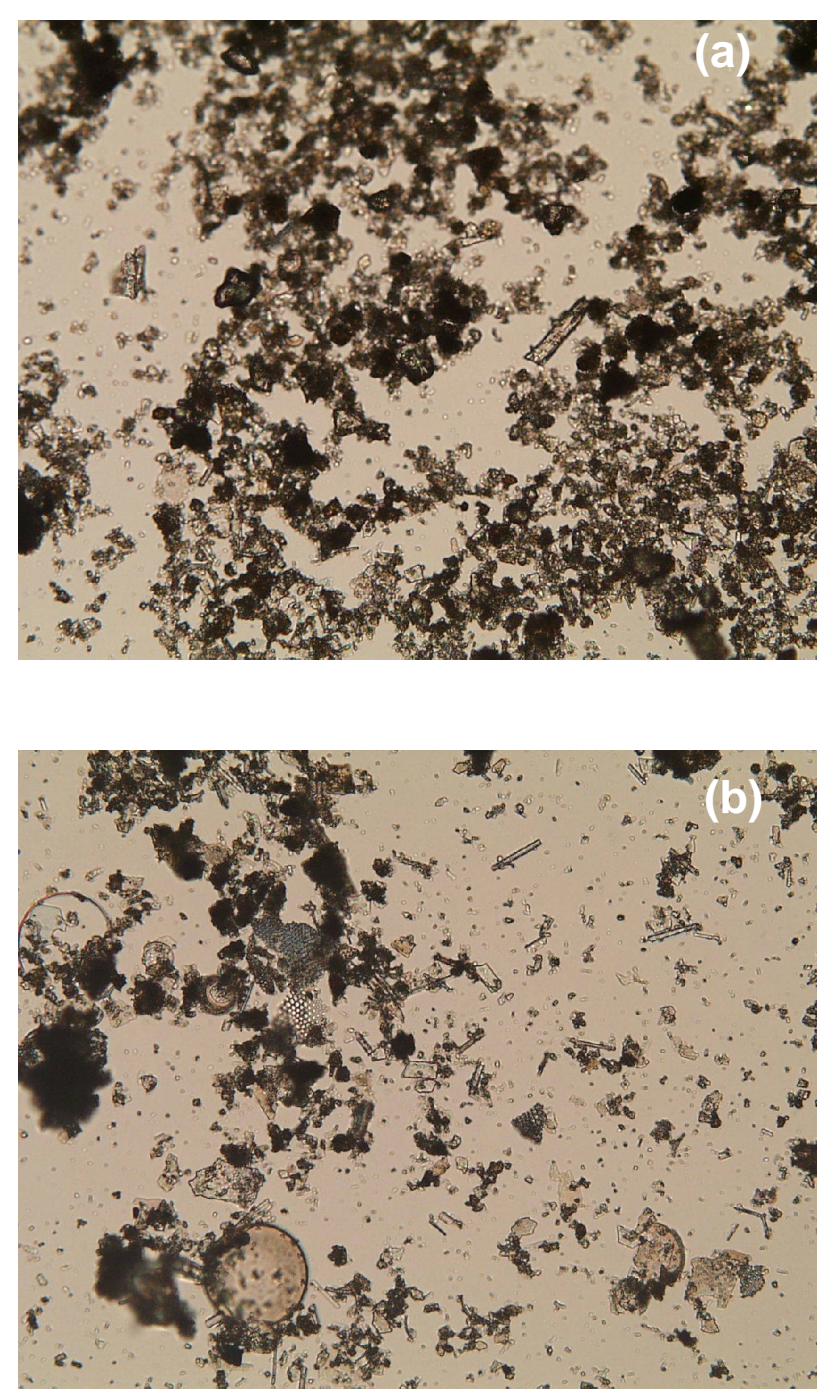

Fig. 4. Polarized microphotographs of a smear-slide of (a) a lightcoloured lamina and (b) a dark-coloured lamina, showing higher abundances of mineral particles and diatom remains, respectively.

Excess ${ }^{210} \mathrm{~Pb}$ is present down to $25 \mathrm{~cm}$ depth, showing a log-linear downcore decrease with accumulated mass (Fig. 3). Excess ${ }^{210} \mathrm{~Pb}$ yields an average sediment accumulation rate of $0.047 \pm 0.002 \mathrm{~g} \mathrm{~cm}^{-2} \mathrm{y}^{-1}\left(r^{2}=0.96\right)$. This rate roughly agrees with the downcore distribution of ${ }^{241} \mathrm{Am}$ and ${ }^{137} \mathrm{Cs}$, which show peaks at ca. $7 \mathrm{~cm}$ depth (not shown). Excess ${ }^{228} \mathrm{Th}$ is present in the top layer, confirming the recovery of the sediment/water interface. The sediment accumulation rate was divided by the mean value of $\rho$ in the upper $25 \mathrm{~cm}$ to yield an average sedimentation rate of $2.2 \mathrm{~mm} \mathrm{y}^{-1}$. Since the thickness of the finest couplets of dark and light laminae are from 2 to $5 \mathrm{~mm}$, some laminae may represent annual layers of sedimentation. Applying the constant sediment accumulation rate for the whole sediment core suggests that the slump segment at $\sim 54 \mathrm{~cm}$ depth corresponds to the mid-eighteenth century. We hypothesize that this slump coincides with a strong earthquake in 1746, which was followed by a tsunami 


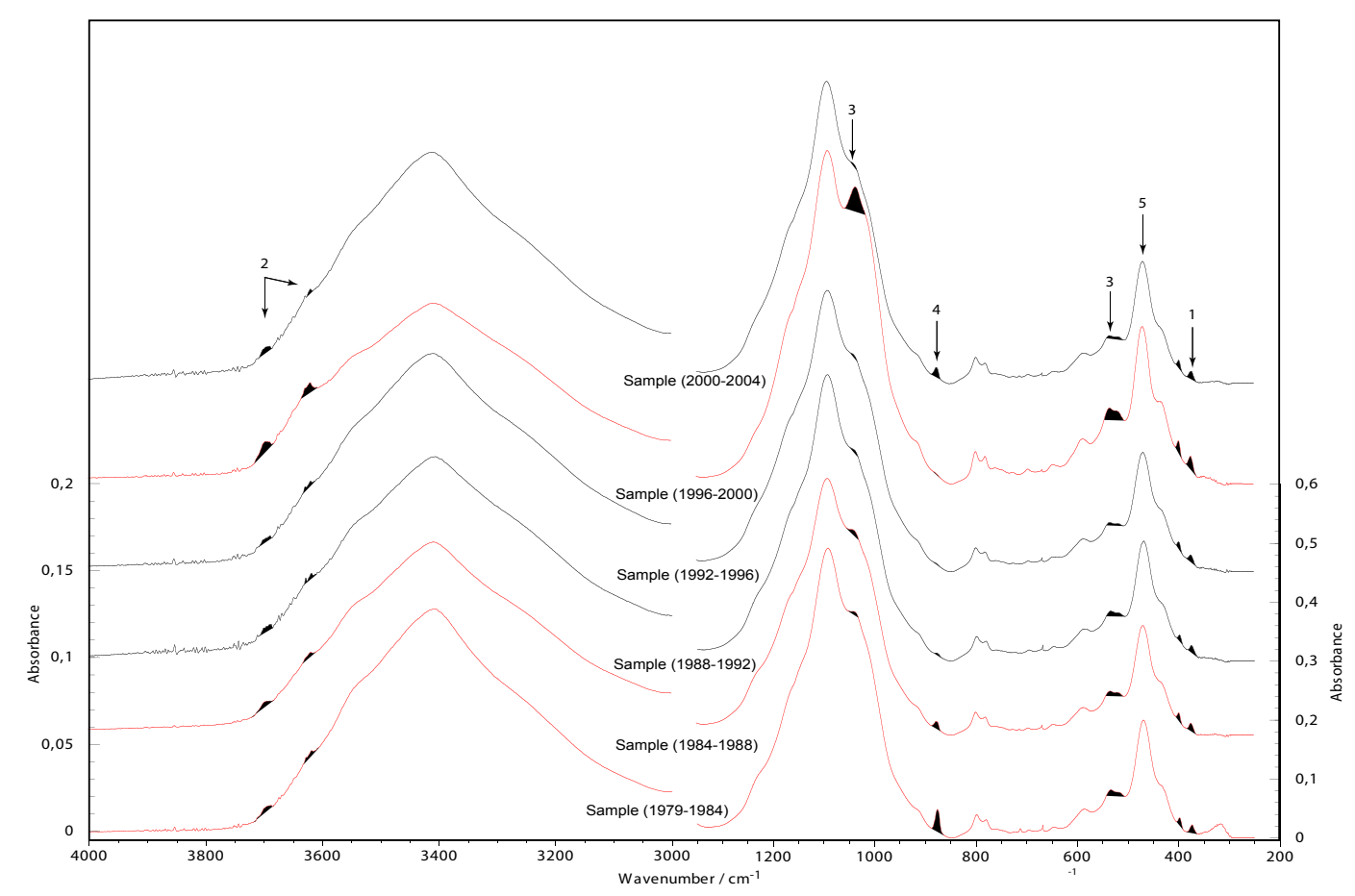

Fig. 5. FTIR spectra of the six upper sampling intervals $(0-4.65 \mathrm{~cm})$, showing the amplitude of absorbance vs wavenumber $\left(\mathrm{cm}^{-1}\right)$. The numbers indicate absorbance of 1) quartz, 2) kaolinite, 3) feldspar, 4) calcite (authigenic mineral), and 5) total silicates (terrigenous material). The variations of these absorbances show higher input of quartz, kaolinite and feldspar in intervals that include El Niño events (red lines) than in intervals with normal years (black lines). Black shading of some small peaks emphasizes the relative differences in absorbance between these sampling intervals.

that impacted the central Peruvian coast, completely destroying the port of Callao. Following this assumption, the $34 \mathrm{~cm}$ transition is dated at ca. 1850 .

Combined evidence thus indicates that the mid-nineteenth century is a transitional period in terms of sediment density, total organic carbon content, and formation of laminae. The higher TOC values in the upper segment (the 12 uppermost sampling intervals corresponding to $\sim 50$ years) indicate a net TOC flux increase, although with significant multiannual variability superimposed. This 50 year period coincides with a trend of increasing upwelling favorable winds in instrumental records (Jahncke et al., 2004), suggesting that the augmentation of TOC flux results from higher primary production. An increase in TOC flux is also present at the same period in laminated sediments at Mejillones Bay $\left(23^{\circ} \mathrm{S}\right)$ off northern Chile (Valdés et al., 2004; Vargas, 2002; Vargas et al., 2004), suggesting that these positive trends of inferred upwelling and primary production occur at a regional scale.

FTIR analyses show that the sediment is composed of quartz, feldspar, kaolinite, illite and amorphous silica. Polarized microphotographs of smear-slides show that concentrations of mineral particles are higher in light laminae and that amorphous silica, corresponding to diatom fragments (primarily Thalassionema nitzchioides, Thalassionema bacillare and resting spores of Chaetoceros spp.), is a primary constituent of dark laminae (Fig. 4). Note that lighter (darker) layers in the x-radiograph are also lighter (darker) in the pho- tographic image. Light laminae and layers with thicker light laminae tend to present higher gray levels and higher $\rho$, respectively, and vice versa. Since the laminae couplets reflect an alternation in the sedimentation, with dark (biogenic) laminae deposited during more productive periods, the finely laminated sequence deposited before the mid-nineteenth century may be interpreted as an increase in seasonality of terrigenous and biogenous sedimentation.

Figure 5 shows the FTIR spectra of six different sampling intervals from the upper layers of the boxcore that span the last 25 years. Increases in the mineral fraction (quartz, feldspar, kaolinite and illite) were present in three sampling intervals that include El Niño events (1982-1983, 1986-1987 and 1997-1998), which can be interpreted as resulting from increased terrigenous input to the continental Peruvian margin. Higher deposition of terrigenous material in this area, where riverine sources are scarce, can result from a combination of increased fluvial discharges due to a greater regional rainfall (Bendix, 2000; Bendix et al., 2003) and enhanced poleward transport during the EN events (Strub et al., 1998 and references therein).

\section{Conclusions}

A boxcore collected off Pisco provides a continuous record of oceanographic and climatic changes during the last 100 to 
250 years. Periods of mineral fractions increase, as those including the 1982-1983, 1986-1987 and 1997-1998 El Niño episodes, may be interpreted as resulting from a combination of increased regional fluvial discharges and enhanced poleward transport during the EN events. A change in sedimentological characteristics and variability of TOC is observed at ca. 1850, reflecting noteworthy changes in climate and ecosystem properties, (e.g. relatively higher seasonality in the fluxes of terrigenous components versus biogenous components prior to that stratigraphic level). Multidecadal variability of TOC is present over the past 150 years, including a positive trend in TOC for the past 50 years. Taking into account instrumental records of increasing alongshore wind stress off Peru and a similar pattern for the TOC flux off the northern Chilean coast during the last half century, we infer a regional intensification of the upwelling regime with enhanced primary productivity.

Acknowledgements. We deeply thank the Instituto del Mar del Perú (IMARPE) for full support of this research. We acknowledge the crew of the RV José Olaya Balandra and other scientific participants in the box-coring survey: E. Enríquez, J. Ledesma, R. Marquina, L. Quipúzcoa, J. Solís, and L. Vásquez, without their support this research could not have taken place. M. Gutiérrez and G. Herbozo kindly contributed the bathymetric map off Pisco shown in Fig. 1. M. Mandeng-Yogo, S. Caquineau and M. García from the IRD Research Unit Paléotropique contributed in several analytical tasks that were used for this research. We also acknowledge the Geology and Oceanography Department of the University of Bordeaux I, France, where the SCOPIX analyses were done. This research was financed by: IMARPE, the IAI Small Grant Program Round 2 project No. 03SGP211-222, IRD Research Unit Paléotropique, IRD DSF Scientific Short-term Exchange Fellowship for D.G., the IAI Collaborative Research Network EPCOR (Eastern Pacific Consortium for Oceanic Research), and the AIEA Coordinated Research Project "Nuclear and isotopic studies of El Niño Phenomenon in the Ocean", research contract No. 12789. This study was also supported and conducted in the frame of the EU-project CENSOR (Climate variability and El Nino Southern Oscillation: Impacts for natural resources and management, contract 511071) and is CENSOR publication 0006.

Edited by: P. Fabian and J. L. Santos

Reviewed by: two anonymous referees

\section{References}

Alheit, J. and Niquen, M.: Regime shifts in the Humboldt Current Ecosystem, Prog. Oceanogr., 60, 201-222, 2004.

Appleby, P. G. and Oldfield, F.: The calculation of lead-210 dates assuming a constant rate of supply of unsupported ${ }^{210} \mathrm{~Pb}$ to the sediment, Catena, 5, 1-8, 1978.

Arntz, W. and Fahrbach, E.: El Niño: experimento climático de la naturaleza. Causas físicas y efectos biológicos, Fondo de Cultura Económica, México, D.F, 309 p., 1996.

Bendix, J.: A comparative analysis of the major El Niño events in Ecuador and Peru over the last two decades, Zbl. Geol. \& Paläontol, Teil I 1999, H. 7/8, 1119-1131, 2000.

Bendix, A., Bendix, J., Gämmerler, S., Reudenbach, Ch., and Weise, S.: The El Niño 1997/98 as seen from space - rainfall re- trieval and investigation of rainfall dynamics with GOES-8 and TRMM data, Proceedings 2002 Met. Sat. Users' Conf., Dublin, 2-6 September 2002, EUMETSAT, 647-652, 2003.

Bertaux, J., Frohlich, F., and Ildefonse, Ph.: A new application of FTIR spectroscopy for the quantification of amorphous and crystallized mineral phases, Example of organic rich sediments, J. Sediment. Res., 68, 3, 440-447, 1998.

Chávez, F., Ryan, J., Lluch-Cota, S., and Ñiquen, M.: Climate, fish, ocean productivity, and atmospheric carbon dioxide, Science, 299, 217-221, 2003.

Cobb, K. M., Charles, C. D., Edwards, R. L., Cheng, H., and Kastner, M.: El Niño-Southern Oscillation and tropical Pacific climate during the last millennium, Nature, 424, 271-276, 2003.

Cochran, K.: The oceanic chemistry of the U- and Th-series nuclides, in: Uranium series disequilibrium: Applications to earth, marine and environmental sciences, edited by: Ivanovich, M. and Harmon, R., Clarendon Press, Oxford, pp. 384-430, 1992.

Field, D. B. and Baumgartner, T. R.: A 900 year stable isotope record of inter-decadal and centennial change from the California Current, Paleoceanography, 15, 695-708, 2000.

Hsieh, C. H., Glaser, S. M., Lucas, A. J., and Sugihara, G.: Distinguishing random environmental fluctuations from ecological catastrophes for the North Pacific Ocean, Nature, 435, 336-340, doi:10.1038/nature02553, 2005.

Jahncke, J., Checkley, D., and Hunt, G. L.: Trends in carbon flux to seabirds in the Peruvian upwelling system: effects of wind and fisheries on population regulation, Fisheries Oceanography, 13 (3), 208, doi:10.1111/j.1365-2419.2004.00283.x, 2004.

Kemp, A. E.: Sedimentary fabrics and variation in lamination style in Peru continental upwelling sediments, in: Proceedings of the Ocean Drilling Project, Scientific Results, ODP, edited by: Suess, E., Von Huene, R., Emeis, K., Bourgois, J., et al., College Station, Texas, 112, 45-58, 1990.

Krissek, L. A. and Scheidegger, K. F.: Environmental controls on sediment texture and composition in low oxygen zones off Peru and Oregon, in: Coastal upwelling; its sediment record, Part B: Sedimentary records of ancient coastal upwelling, edited by: Suess, E. and Thiede, J., Plenum Press, New York, pp. 163-180, 1983.

Levin, L. A., Gutiérrez, D., Rathburn, A., Neira, C., Sellanes, J., Muñoz, P., Gallardo, V. A., and Salamanca, M.: Benthic processes on the Peru Margin: A transect across the oxygen minimum zone during the 1997-98 El Niño, Prog. Oceanogr., 53, $1-27,2002$.

Mantua, N. J. and Hare, S. R.: The Pacific decadal oscillation, J. Oceanogr., 58, 35-44, 2002.

Migeon, S., Weber, O., Faugeres, J.-C., and Saint-Paul, J.: SCOPIX: a new X-ray imaging system for core analysis, GeoMarine Lett., 18, 251-225, 1999.

Miller, A., Cayan, D. R., Barnett, T. P., Graham, N. E., Oberhuber, J.: Interdecadal variability of the Pacific Ocean: model response to observed heat flux and wind stress anomalies, Clim. Dyn., 9, 287-302, 1994.

Organization Panamericana de la salud (OPS): Crónicas de desastres, Fenómeno El Niño - 1997-1998, Washington, 2000.

Reinhardt, L., Kudrass, H.-R., Lückge, A., Wiedicke, M., Wunderlich, J., and Wendt, G.: High-resolution sediment echosounding off Peru: Late Quaternary depositional sequences and sedimentary structures of a current-dominated shelf, Mar. Geophys. Res., 23, 335-351, 2002.

Reyss, J.-L., Schmidt, S., Legeleux, F., and Bonté P.: Large, low background well-type detectors for measurements of en- 
vironmental radioactivity, Nuclear Instruments and Methods in Physics Research A, 357, 391-397, 1995.

Schwartzlose, R., Alheit, J., Bakun, A., Baumgartner, T., Cloete, R., Crawford, R., Fletcher, W., Green-ruiz, Y., Hagen, E., Kawasaki, T., Lluch-Belda, D., Lluch-cota, S., Maccall, A., Matsuura, Y., Nevarez-Martinez, M., Parrish, R., Roy, C., Serra, R., Shust, K., Ward, N., and Zuzunaga, J.: Worldwide large-scale fluctuations of sardine and anchovy populations, S. Afr. J. Mar. Sci., 21, 289347, 1999.

Strub, P. T., Mesías, J. M., Montecino, V., and Rutllant, J.: Coastal ocean circulation off western South America, in: The global coastal ocean, edited by: Robinson, A. R. and Brink, K. H., The Sea, Vol. 11, Interscience, New York, p. 273-313, 1998.

Suess, E., Von Huene, R., Emeis, K., Bourgois, J., et al.: Proceedings of the Ocean Drilling Program, Scientific Results, Vol. 112, 738 p., 1990.

Valdés, J., Ortlieb, L., and Sifeddine, A.: Variaciones del sistema de surgencia de Punta Angamos $\left(23^{\circ} \mathrm{S}\right)$ y la Zona de Mínimo de Oxígeno durante el pasado reciente: una aproximación desde el registro sedimentario de la Bahía Mejillones del Sur. Rev. Chil. Hist. Nat. ,76 (3): 347-362., 2003.

Valdés, J., Sifeddine, A., Lallier-Verges, E., and Ortlieb, L.: Petrographic and geochemical study of organic matter in surficial laminated sediments from an upweling system (mejillones del Sur Bay, northern chile), Org. Geochem., 35, 881-894, 2004.
Vargas, G.: Interactions océan-atmosphère au cours des derniers siècles sur la côte du Désert d'Atacama: analyse multi-proxies des sédiments laminés de la baie de Mejillones (23 $\mathrm{S}), \mathrm{Ph} . \mathrm{D}$. Thesis, Université Bordeaux I, 290 p., 2002.

Vargas, G., Ortlieb, L., Pichon, J. J., Bertaux, J., and Pujos, M.: Sedimentary facies and high resolution primary production inferences from laminated diatomaceous sediments off northern Chile $\left(23^{\circ} \mathrm{S}\right)$, Mar. Geol., 211, 79-99, 2004.

Wang, C. and Picaut, J.: Understanding ENSO physics - A review, in: Earth's Climate: The Ocean-Atmosphere Interaction, edited by: Wang, C., Xie, S.-P., and Carton, J. A., AGU Geophysical Monograph Series, 147, 21-48, 2004.

Wang, C., Xie, S.-P., and Carton, J. A.: A global survey of oceanatmosphere interaction and climate variability, in: Earth's Climate: The Ocean-Atmosphere Interaction, edited by: Wang, C., Xie, S.-P., and Carton, J. A., AGU Geophysical Monograph Series, 147, 1-19, 2004

Wang, C. and Fiedler, P. C.: ENSO variability and the eastern tropical Pacific: A review, Prog. Oceanogr., in press, 2005. 